\title{
Year-round acoustic detection of bearded seals (Erignathus barbatus) in the Beaufort Sea relative to changing environmental conditions, 2008-2010
}

\author{
Kalyn Q. MacIntyre • Kathleen M. Stafford • \\ Catherine L. Berchok · Peter L. Boveng
}

Received: 19 November 2012/Revised: 20 March 2013/Accepted: 2 May 2013/Published online: 19 May 2013

(C) The Author(s) 2013. This article is published with open access at Springerlink.com

\begin{abstract}
Bearded seals (Erignathus barbatus) are panArctic pinnipeds that are often seen in association with pack ice, and are known for their long, loud trills, produced underwater primarily in the spring. Acoustic recordings were collected from August 2008 to August 2010 at two locations and a single year (2008-2009) at a third location, in the western Beaufort Sea. Three recorders in 2008-2009 had a $30 \%$ duty cycle and a bandwidth of $10-4,096 \mathrm{~Hz}$. One recorder in 2009-2010 had a $45 \%$ duty cycle and a bandwidth of 10-4,096 Hz and the second had a $20 \%$ duty cycle and bandwidth of 10-8,192 Hz. Spectrograms of acoustic data were examined for characteristic patterns of bearded seal vocalizations. For each recorder, the number of hours per day with vocalizations was compared with in situ water temperature and satellite-derived daily sea ice concentrations. At all sites, bearded seals were vocally active yearround. Call activity escalated with the formation of pack ice in the winter and the peak occurred in the spring, coinciding with mating season and preceding breakup of the sea ice. There was a change in the timing of seasonal sea ice formation and retreat between the two consecutive years that was reflected in the timing of peak bearded seal call activity. This study provides new information on fall and winter
\end{abstract}

K. Q. MacIntyre ( $\square)$

School of Aquatic and Fishery Sciences, University of Washington, 1122 NE Boat St., Seattle, WA 98105, USA e-mail: kalyn.macintyre@noaa.gov

K. Q. MacIntyre · C. L. Berchok · P. L. Boveng National Marine Mammal Laboratory, Alaska Fisheries Science Center, National Marine Fisheries Service, NOAA Fisheries Service, 7600 Sand Point Way NE, Seattle, WA 98115, USA

K. M. Stafford

Applied Physics Laboratory, University of Washington,

1013 NE 40th St., Seattle, WA 98105, USA bearded seal vocal behavior and the relationship between year-round vocal activity and changes in annual sea ice coverage and in situ water temperature.

Keywords Bearded seal · Erignathus barbatus $\cdot$ Beaufort Sea $\cdot$ Acoustics $\cdot$ Sea ice concentration

\section{Introduction}

Climate disruption and warming of the Arctic is causing a rapid shift in environmental stability, especially at high latitudes (Walsh 2008; Maslanik et al. 2011; Timmermans et al. 2011; Woodgate et al. 2012). The increased variability caused by warming challenges the capacity of Arctic species to adapt to these changes (Moore and Huntington 2008). Ice-obligate species such as the polar bear (Ursus maritimus), walrus (Odobenus rosmarus), ringed seal (Phoca hispida), and bearded seal (Erignathus barbatus) will have more difficulty adapting to this change than temperate or seasonally migrant species that have the ability to extend their geographic range (Moore and Huntington 2008). Declining seasonal sea ice extent, delayed freeze-up, and accelerated spring breakup are likely to reduce the available habitat for resting, breeding, molting and hunting, posing the greatest threat to the survival of ice-obligate species (Moore and Huntington 2008). Due to the threats posed by diminishing sea ice, the National Oceanic and Atmospheric Administration (NOAA) has proposed that bearded seals and ringed seals be listed as threatened under the US Endangered Species Act of 1973 (73 FR 16617).

Bearded seals are a pan-Arctic pinniped widely distributed throughout the northern Bering, Chukchi, and Beaufort Seas (BCB) and are most abundant north of the 
ice edge zone and south of the Bering Strait (Burns 1981). They maintain a close association with sea ice for critical life history activities, such as reproduction and molting (Burns 1970, 1981; Nelson et al. 1984; Moore and Huntington 2008). In the spring, large numbers of bearded seals move north as the seasonal sea ice retreats and subsequently move south in the autumn/winter as sea ice forms (Potelov 1969; Burns 1981; Simpkins et al. 2003; Frost et al. 2008). Bearded seals occupy spring pack ice (Simpkins et al. 2003) and generally prefer to be near polynyas and other natural openings in sea ice for breathing, hauling out, and access to prey (Nelson et al. 1984; Stirling 1997). Their life histories are linked to seasonal changes in ice conditions; therefore, any extreme variation in their sea ice habitat may have a considerable effect on the persistence of the population. Variability in water temperature and climate patterns may also pose risks for bearded seal populations. The Alaska Coastal Current (ACC) runs along the northwestern Alaskan coast and is composed of warm water intrusions from the Bering and Chukchi Seas (Okkonen et al. 2009). Changes in climate patterns in the Chukchi Sea (e.g., wind) have been shown to influence water temperature flowing through the ACC off Barrow, $\mathrm{AK}$ in the summer months. The variability due to wind (storms) as well as water temperatures may impact the distribution of prey or affect the reproductive cycle of marine mammal species (Atkinson 1997; Ashjian et al. 2010).

Bearded seals are highly vocal and use elaborate underwater vocalizations to advertise breeding condition or establish aquatic territories (Van Parijs et al. 2004; Risch et al. 2007). They produce a series of frequency modulated (FM) calls that typically range in frequency from 130 to 4,800 Hz (Ray et al. 1969; Stirling et al. 1983). Captive studies have shown that males are the primary source of underwater vocalizations (Ray et al. 1969; Davies et al. 2006), producing reproductive displays consisting of long loud trills (Van Parijs and Clark 2006). Their predominant call type consists of several variations of a long FM trill in addition to moans and groans. A typical trill will propagate between 5 and $10 \mathrm{~km}$, however, some can propagate more than $20 \mathrm{~km}$ and last as long as $3 \mathrm{~min}$ (Cleator et al. 1989). Bearded seal vocalizations have been studied in great detail during their reproductive season, which is thought to be roughly April to June (McLaren 1958). However, little information is available for vocalizations produced outside this period, particularly during autumn and winter, during which time bearded seals are believed to be vocally inactive (Van Parijs et al. 2001).

Previous passive acoustic research in the Beaufort Sea focused on the deployment of recorders during the spring months only. Due to increased interest in the Arctic and the effects of climate change on marine mammals in this region, the use of year-round passive acoustic recordings has increased providing long-term data on whale, seal, and human activity in the Bering, Chukchi, and Beaufort Seas (Delarue et al. 2009; Moore et al. 2012; Roth et al. 2012). Here, we present the first year-round recordings of bearded seals at three locations in the Beaufort Sea over a 2-year period and compare these to in situ water temperature and sea ice concentrations around each location. This study demonstrates a tight coupling between the presence of vocally active bearded seals and the condition of their surrounding sea ice habitat and provides new information on the year-round vocal activity of bearded seals in the Beaufort Sea.

\section{Methods}

Passive acoustic recorders (Aural-M2, http://www.Multi Electronique.com) were deployed on three subsurface oceanographic moorings (Fig. 1) in the Beaufort Sea over a 2 -year period. These instruments recorded in the frequency range $10-4,096 \mathrm{~Hz}$ or $10-8,192 \mathrm{~Hz}$ (Table 1). Instrument packages were set to record for an entire year, and sampling rates were sufficient for recording a range of acoustic energy from low frequency baleen whale calls to some of the high frequency calls produced by toothed whales. During the first year, three recorders were deployed in August 2008 (A1, A2, A3). Each recorder in 2008-2009 was set to record on a $30 \%$ duty cycle, where the first $9 \mathrm{~min}$ out of every $30 \mathrm{~min}$ period for each day $(24 \mathrm{~h})$ was recorded. All three instruments were recovered in 2009, and two of these were subsequently redeployed (Table 1). The instruments redeployed in August of 2009 were recovered 1 year later. One instrument deployed in 2009-2010 was set to record on a $20 \%$ duty cycle (14 min every hour), while the other was set to $45 \%$ duty cycle (9 min every $20 \mathrm{~min}$ ). All recorders were suspended $5 \mathrm{~m}$ above the seafloor to minimize the risk of disturbance or damage from overhead ice keels. Archived digital acoustic data were downloaded from each recorder. For both years, full 9 or 14 min spectrograms (e.g., Fig. 2, fast Fourier transform (FFT) 2048, $50 \%$ overlap, Hann window) of each acoustic data file from all recorders were visually examined for the presence of bearded seal vocalizations using the program Ishmael 1.0 (Mellinger 2001). A total of 43,296 $\mathrm{h}$ of acoustic data were examined for bearded seal calls. Files with calls were manually identified for presence or absence of bearded seal calls. Bearded seal calling was quantified as a total number of hours per day (h/d) with at least one bearded seal call observed, which will also be referred to as calling activity.

Each recorder was equipped with an internal temperature sensor that recorded water temperature at the 
Fig. 1 Hydrophone locations in the flaw lead polynya in the Alaskan Beaufort Sea from 2008 to 2010. Sea ice depicted $\left(12.5 \mathrm{~km}^{2}\right.$ resolution) is from October 31, 2008 and demonstrates a closing lead. Open water is represented as black and $100 \%$ sea ice concentration as white, with a grayscale gradient representing ice concentrations at $20 \%$ intervals between the minimum and maximum values. Sea ice data were obtained from the National Snow and Ice Data Center (NSIDC, http://n4eil01u. ecs.nasa.gov)

Table 1 Deployment details for 2008-2010

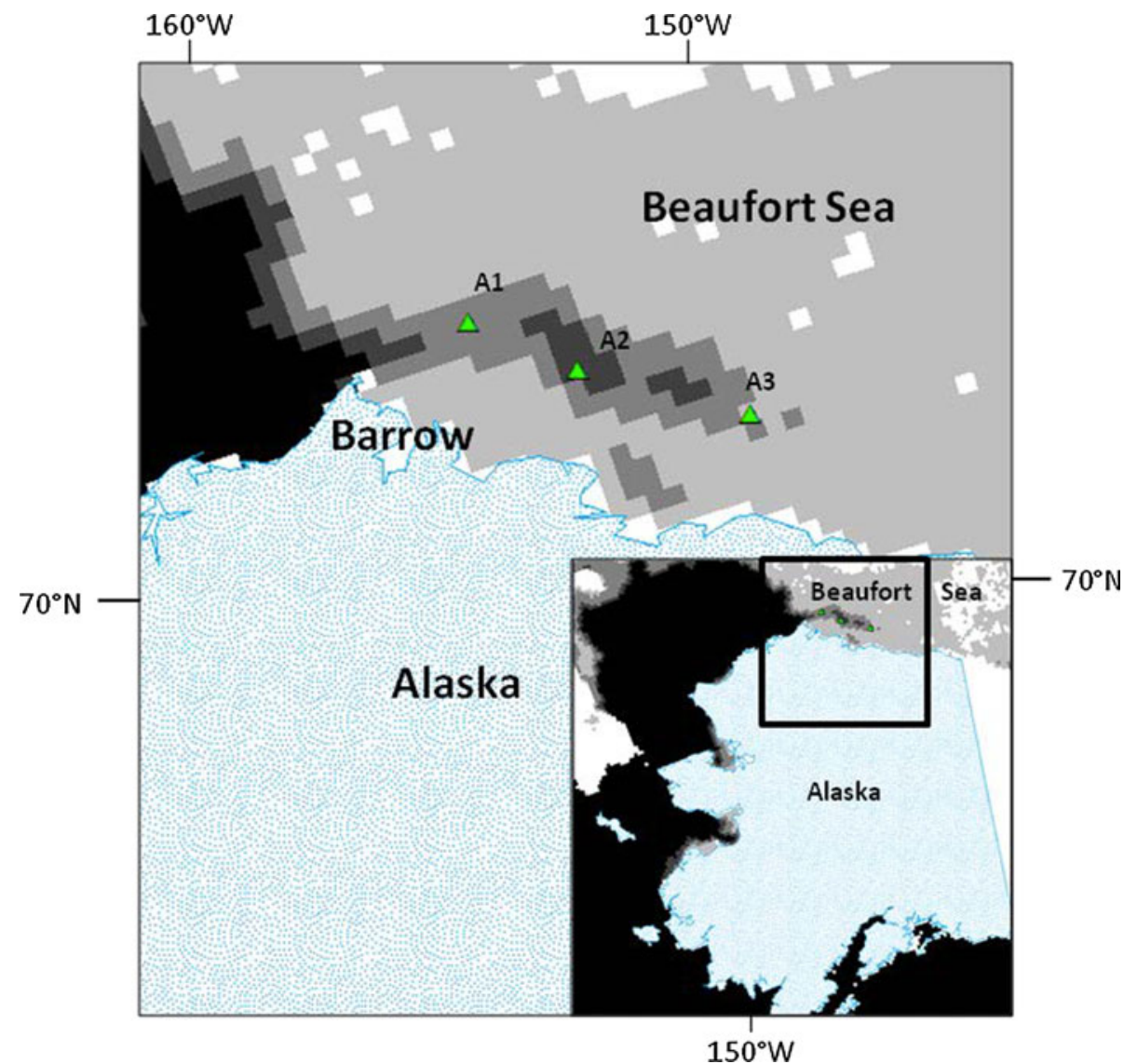

\begin{tabular}{lllccc}
\hline Instrument ID & Location & $\begin{array}{l}\text { Recording } \\
\text { dates }\end{array}$ & $\begin{array}{l}\text { Instrument } \\
\text { depth }(\mathrm{m})\end{array}$ & $\begin{array}{l}\text { Sample rate } \\
(\mathrm{Hz})\end{array}$ & $\begin{array}{l}\text { Duty cycle } \\
(\mathrm{min})\end{array}$ \\
\hline A1 2008 & $71.56 \mathrm{~N} 155.59 \mathrm{~W}$ & $8 / 15 / 08-7 / 27 / 09$ & 94 & 8,192 & $9 / 30$ \\
A2 2008 & $71.46 \mathrm{~N} 152.25 \mathrm{~W}$ & $8 / 15 / 08-8 / 2 / 09$ & 131 & 8,192 & $9 / 30$ \\
A3 2008 & $71.13 \mathrm{~N} 149.46 \mathrm{~W}$ & $8 / 15 / 08-8 / 1 / 09$ & 46 & 8,192 & $9 / 30$ \\
A1 2009 & $71.76 \mathrm{~N} 154.48 \mathrm{~W}$ & $8 / 1 / 09-8 / 14 / 10$ & 102 & 16,384 & $14 / 60$ \\
A2 2009 & $71.45 \mathrm{~N} 152.50 \mathrm{~W}$ & $8 / 4 / 09-8 / 11 / 10$ & 95 & 8,192 & $9 / 20$ \\
\hline
\end{tabular}

beginning of each data file (duty cycle). The temperature sensor had a sensitivity between -10 and $+40{ }^{\circ} \mathrm{C}$ and a resolution of $0.0625^{\circ} \mathrm{C}$. Average daily temperature values were computed from these measurements. Water temperature does not vary substantially from the surface to the bottom in these locations ( $\mathrm{S}$. Okkonen pers. comm.). Therefore, temperature sampled at depth $(5 \mathrm{~m}$ above seafloor) was assumed to represent the water temperature experienced by bearded seals. Sea ice concentration data (AMSR-E Aqua $12.5 \mathrm{~km}$ resolution) used in this study were obtained from the National Snow and Ice Data Center (http://nsidc.org/data/collections.html, Cavalieri et al. 2004). Daily sea ice concentrations were extracted from a buffer with a $20-\mathrm{km}$ radius that was centered on each mooring location. Mean daily sea ice concentrations were averaged at each location using the zonal statistics toolbox in ArcMap 10.0 (ESRI 2011. ArcGIS Desktop: Release 10. Redlands, CA: Environmental Systems Research Institute). While most bearded seal calls were likely within $5 \mathrm{~km}$ of the instruments, approximately $15 \%$ of calls can be heard at distances up to $20 \mathrm{~km}$ (Cleator et al. 1989), therefore, a $20-\mathrm{km}$ radius was chosen to obtain mean daily sea ice concentration values to be sure that the majority of all vocalizing bearded seals within the detectable range were accounted for. Daily water temperature and sea ice concentration at each mooring location were compared with the total number of hours per day with bearded seal calls. 
Fig. 2 Spectrogram displaying example bearded seal calls recorded at location $\mathrm{A} 1$ on March 3, 2010. FFT 2048, $50 \%$ overlap, Hann window

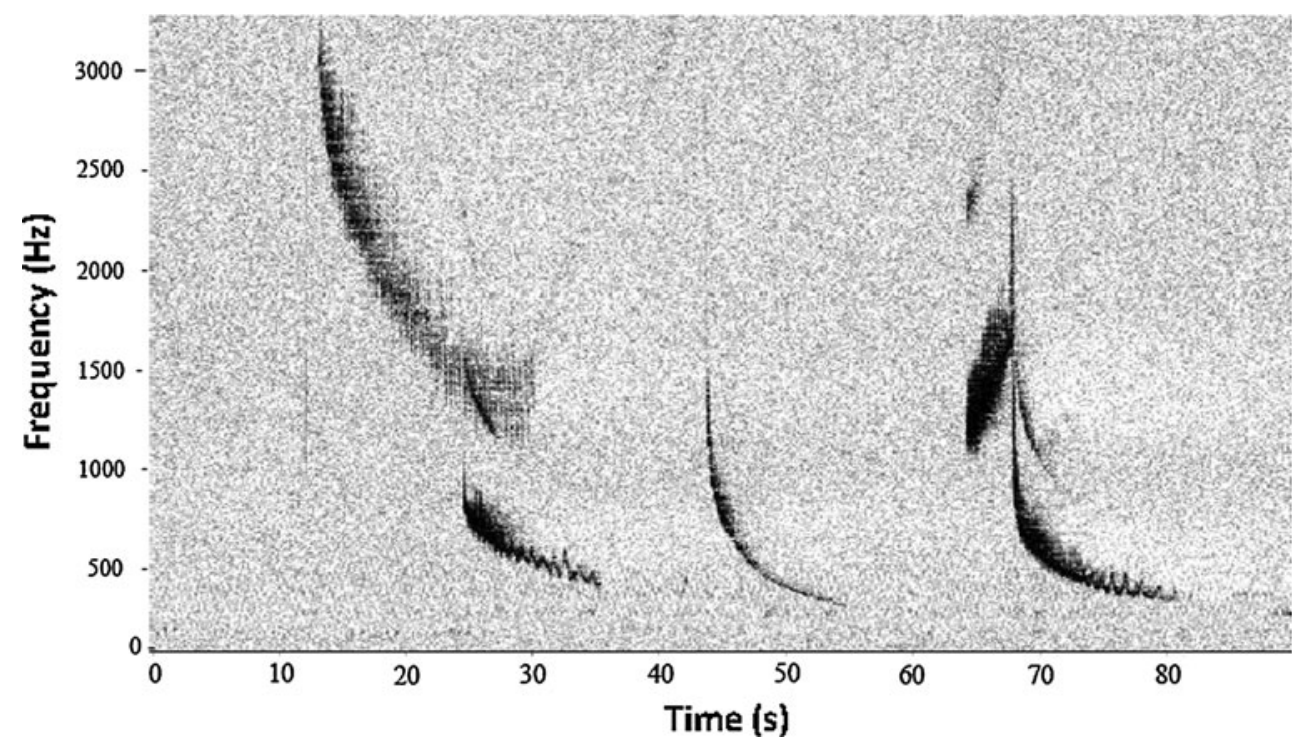

\section{Results}

Bearded seal vocalizations were detected in the Beaufort Sea in all 12 months at sites A1 and A2 from 2008 to 2010 and 11 months at site A3 from 2008 to 2009. Of the $43,296 \mathrm{~h}$ of acoustic data recorded from all sites in both years, vocalizations were identified in $16,030 \mathrm{~h}$ (Table 2). There was, however, strong seasonal variation in the number of hours per day with calls. At all sites, the peak period of hours per day with calls occurred during the spring months and ended in late June, with the exception of site A1, where the peak period began in January rather than March (Figs. 3a, 4a, 5a). The fewest hours per day with calls at each site occurred from July to December although in both years at each location there was an increase (up to $15 \mathrm{~h} / \mathrm{d}$ ) in the hours per day with calls in late September or early October. At all recorder locations for both years of the study, the minimum number of hours with bearded seal calls occurred in the months of August and November.

\section{Site A1}

Bearded seal calls were recorded at site A1 (westernmost site, Fig. 1) from August 19, 2008, through July 17, 2009 , and from August 1, 2009, to August 12, 2010. Few calls were present from July to mid-September 2008. In midSeptember, call activity increased to over $15 \mathrm{~h} / \mathrm{d}$ and then dropped back down in October. Call activity increased again in mid-December with calls present nearly every hour of the day beginning in February. This trend held until early July. A similar pattern was seen in the second year of recording, but the late summer increase $(9 \mathrm{~h} / \mathrm{d})$ occurred in early October 2009 and calls were present nearly $24 \mathrm{~h} / \mathrm{d}$ from March to early July 2010 (Fig. 3a). The percentage of
Table 2 Recording details for each location 2008-2010

\begin{tabular}{llll}
\hline Instrument ID & $\begin{array}{l}\text { Total recorded } \\
\text { hours }\end{array}$ & $\begin{array}{l}\text { Number of } \\
\text { hours with calls }\end{array}$ & $\begin{array}{l}\text { Percent hours } \\
\text { with calls (\%) }\end{array}$ \\
\hline A1 2008 & 8,328 & 4,474 & 53.7 \\
A2 2008 & 8,472 & 2,367 & 27.9 \\
A3 2008 & 8,448 & 2,865 & 33.9 \\
A1 2009 & 9,096 & 4,217 & 46.4 \\
A2 2009 & 8,952 & 2,107 & 23.5 \\
\hline
\end{tabular}

the total hours with bearded seal calls at A1 was similar between years (Table 2): $53.7 \%$ in 2008-2009 and $46.4 \%$ in 2009-2010.

Sea ice began to form at A1 on October 21, 2008, and increased to greater than $90 \%$ mean concentration by November 7, 2008 (Fig. 3b). Maximum sea ice concentration (95-100\%) lasted from early November 2008 until June 30, 2009, when it dropped to approximately $75 \%$ and then continued to decline rapidly; the mooring was in open water by 18 July 18,2009 . Sea ice around A1 began to form again on about November 14, 2009, and increased rapidly to greater than $80 \%$ mean concentration by November 21, 2009. Maximum sea ice concentration persisted until July 15, 2010, when it dropped below $80 \%$ and continued to decrease. By August 5, 2010, the area around the mooring was in open water.

During the first year of deployment (2008-2009), in situ water temperature at $\mathrm{A} 1$ ranged from $-1.8^{\circ}$ to $0.5^{\circ} \mathrm{C}$ with a mean temperature of $-1.4{ }^{\circ} \mathrm{C}$ (Fig. 3c). During the second year (2009-2010), the overall mean temperature was almost $1{ }^{\circ} \mathrm{C}$ higher $\left(-0.7{ }^{\circ} \mathrm{C}\right.$, range $-1.8^{\circ}$ to $\left.3.9^{\circ} \mathrm{C}\right)$. From 15 August to 15 September for each year, the greatest difference can be attributed to a late summer pulse of warm 


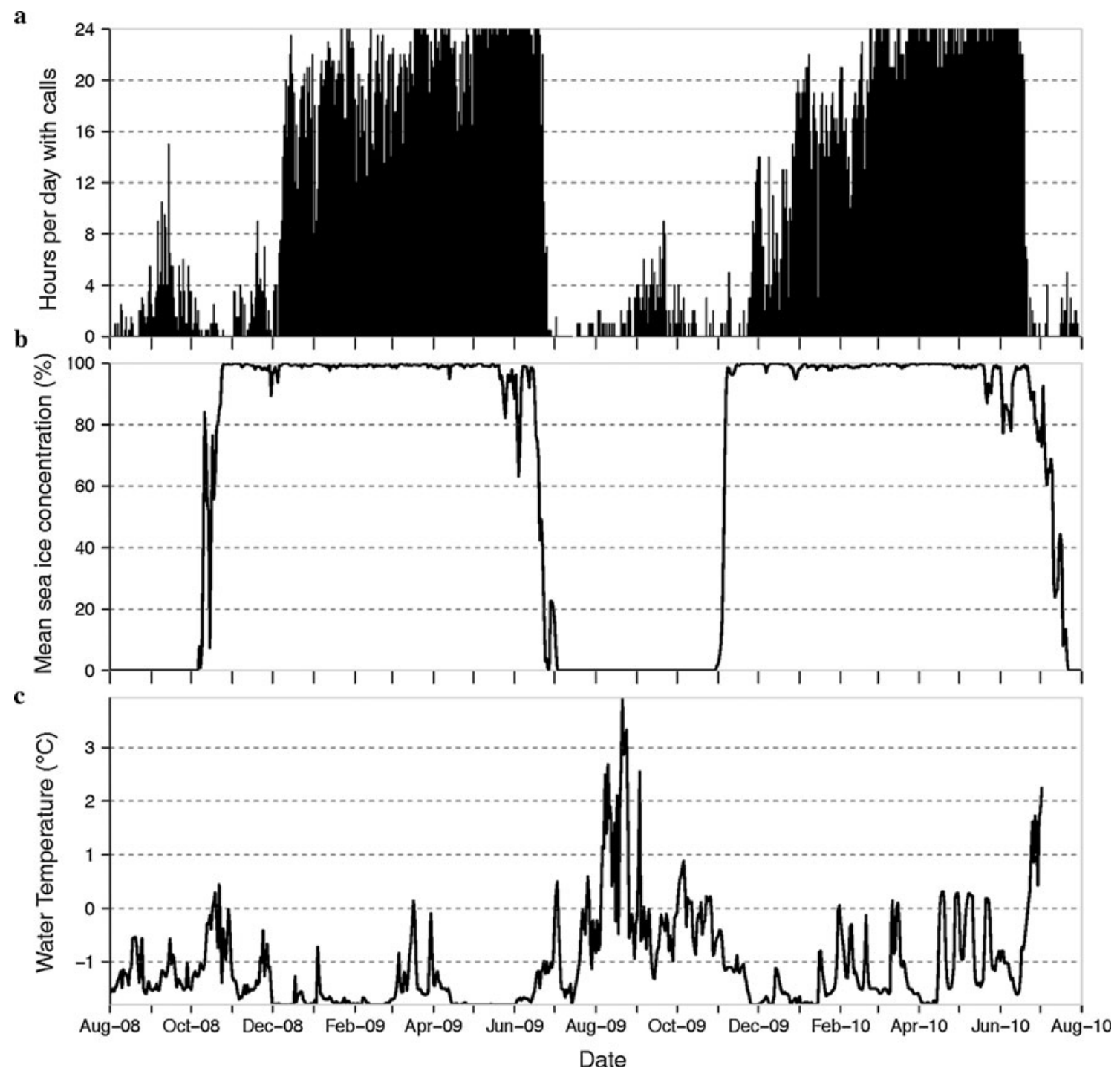

Fig. 3 Acoustic detections of bearded seal vocalizations from August 2008 to August 2010 from site A1 plotted with sea ice concentration and in situ water temperature: a The number of hours per day with bearded seal calls, b AMSR-E daily percent satellite-derived mean sea concentration $(12.5 \mathrm{~km}$ resolution, NSIDC, http://n4eil01u.ecs.

nasa.gov), $\mathbf{c}$ in situ water temperature. In general, the number of hours per day with calls was lower with $0 \%$ sea ice concentration and higher as the sea ice increases to maximum concentration (95-100\%). Site A1 had many more hours over a long time period with calls in both 2008-2009 and 2009-2010 than site A2 or A3

water. In 2008 , the mean temperature was $-1.2^{\circ} \mathrm{C}$, whereas for the same period in 2009 , it was $+1.0^{\circ} \mathrm{C}$.

\section{Site A2}

Calls at A2 (central site, Fig. 1) were recorded year-round with the lowest number of hours with calls occurring in July, August, and November (Fig. 4a). There was a slight peak in call activity, similar to that seen at A1 but with fewer hours per day with calls $(4.5 \mathrm{~h} / \mathrm{d})$, around late September. Bearded seal calls were primarily present at A2 from mid-February 2009 to early July 2009 and again from mid-March 2010 to early July 2010. Calls occurred nearly $24 \mathrm{~h} / \mathrm{d}$ from mid-April through early July 2009, except for a slight drop in calling activity recorded during the last 3 weeks of May, where call activity ranged from 6 to $23.5 \mathrm{~h} / \mathrm{d}$, but with an average less than $15 \mathrm{~h} / \mathrm{d}$ over a 3 -week period. Call activity ceased in early July until midAugust 2009. From late April through late June 2010, calls were present nearly every hour. After this time, the number of hours/day with calls remained low (less than $6 \mathrm{~h} / \mathrm{d}$ ). Similar percentages were observed in 2008-2009 and 2009-2010 when comparing the number of hours with bearded seal calls to the total number of hours recorded (Table 2): 27.9 and $23.5 \%$, respectively.

Sea ice began to form at A2 on October 14, 2008, and by November 6, 2008, the area was completely ice-covered (Fig. 4b). Greater than $90 \%$ sea ice concentration lasted 


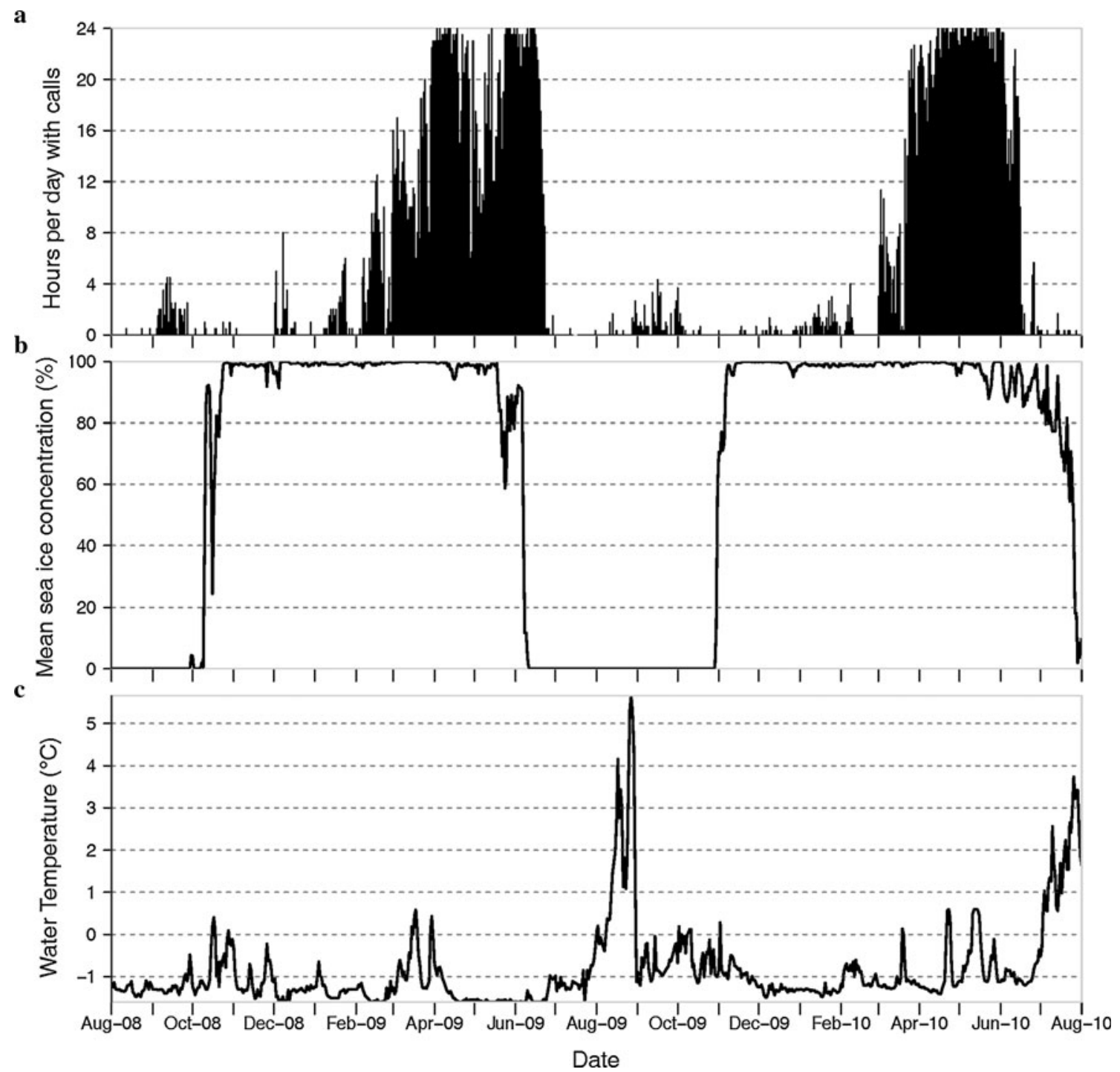

Fig. 4 Acoustic detections of bearded seal vocalizations from August 2008 to August 2010 from site A2 plotted with sea ice concentration and in situ water temperature: a the number of hours per day with

bearded seal calls, b AMSR-E daily percent satellite-derived mean sea concentration $(12.5 \mathrm{~km}$ resolution, NSIDC, http://n4eil01u.ecs. nasa.gov), $\mathbf{c}$ in situ water temperature

from November 6, 2008, until June 21, 2009, when it dropped to approximately $43 \%$ and then decreased rapidly such that the mooring was in open water by June 25, 2009. Sea ice formed again on November 12, 2009, and increased rapidly to greater than $90 \%$ mean concentration by November 21, 2009; 95-100\% sea ice concentration persisted 1 month longer in 2010, until 27 July, at which time it declined to below $90 \%$ and continued to decline to completely open water by August 16, 2010.

During the first year of deployment (2008-2009), in situ water temperature at $\mathrm{A} 2$ ranged from $-1.6^{\circ}$ to $0.6^{\circ} \mathrm{C}$ with a mean temperature of $-1.2{ }^{\circ} \mathrm{C}$ (Fig. $4 \mathrm{c}$ ). During the second year (2009-2010), the overall mean temperature was approximately $0.7{ }^{\circ} \mathrm{C}$ higher with an average temperature of $-0.5{ }^{\circ} \mathrm{C}$ and in situ water temperature ranged from $-1.5^{\circ}$ to $5.7^{\circ} \mathrm{C}$. From 15 August to 15 September, the mean temperature for this time period in 2008 was $-1.1^{\circ} \mathrm{C}$, whereas for the corresponding period in 2009 , it was $+1.7^{\circ} \mathrm{C}$.

Site A3

A recorder was deployed at the A3 location (easternmost site, Fig. 1) for only 1 year during 2008-2009 (Table 1). Bearded seal calls were present at site A3 from September 19, 2008, through July 16, 2009 (Fig. 5a). No calls were recorded prior to mid-September, when call activity increased to $6.5 \mathrm{~h} / \mathrm{d}$. These quickly decreased to zero again 


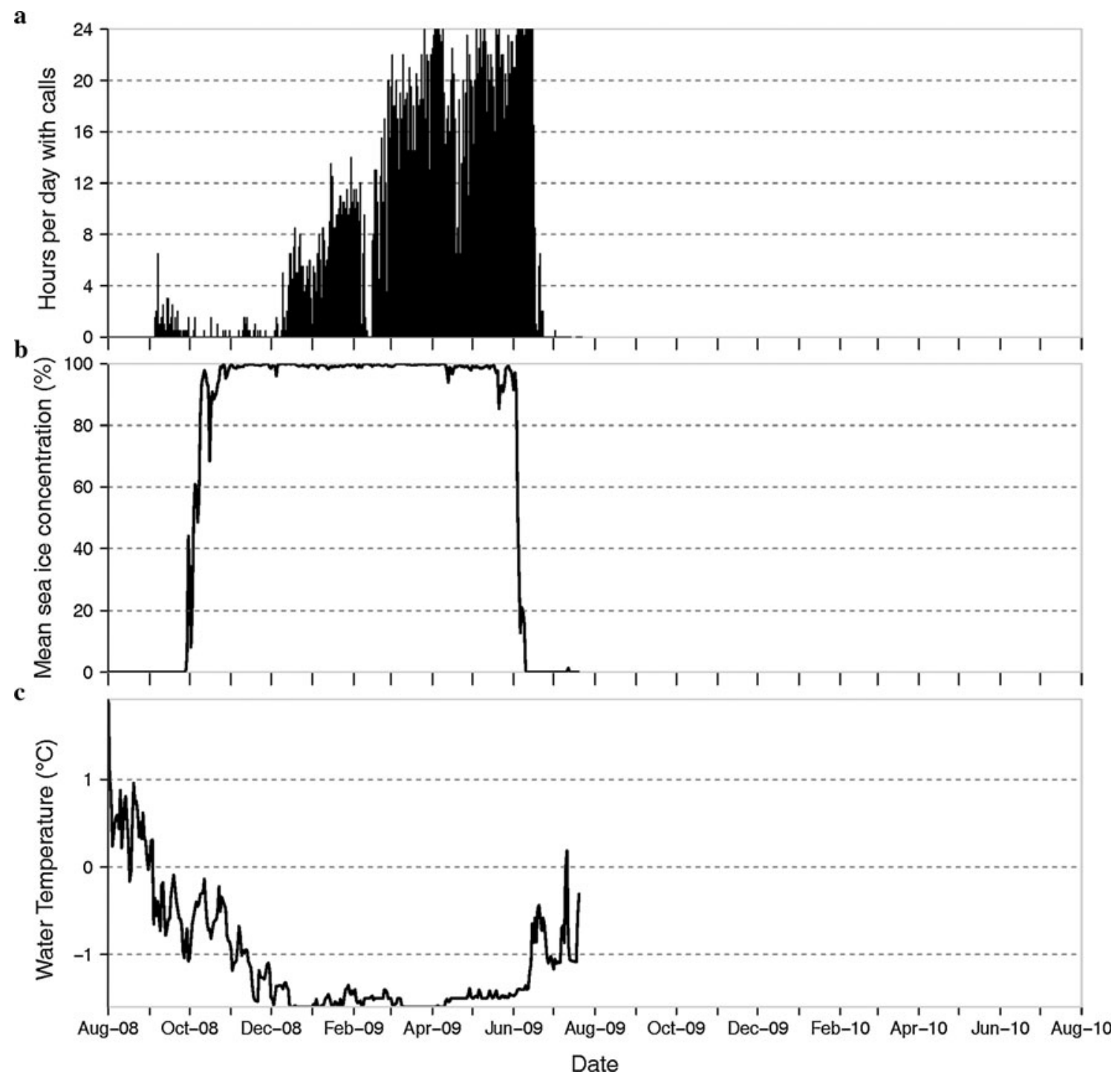

Fig. 5 Acoustic detections of bearded seal vocalizations from August 2008 to August 2009 from site A3 plotted with sea ice concentration and in situ water temperature: a the number of hours per day with bearded seal

calls, b AMSR-E daily percent satellite-derived mean sea concentration (12.5 km resolution, NSIDC, http://n4eil01u.ecs.nasa.gov), $\mathbf{c}$ in situ water temperature. No data were available for 2009-2010 for this site

before increasing for the winter. The number of hours with calls increased gradually from mid-December 2008 to early March 2009, when they dropped off briefly. Calls were present nearly every hour from mid-March until late June 2009 at which time with call activity decreased to near zero. There was a slight drop in call activity in early May that was similar to the one observed at site A2 in 2009, where the number of hour/day with calls ranged from 6.5 to 23.5 and averaged only $16 \mathrm{~h} / \mathrm{d}$ for a 2 -week period. Bearded seal calls were detected in $33.9 \%$ of the total recorded hours at A3 during 2008-2009 (Table 2).

Sea ice began to form at A3 on October 13, 2008, and remained above $90 \%$ mean concentration from November 1, 2008, to June 16, 2009 (Fig. 5b). Ice concentration continued to rapidly decline, and the instrument was in open water 8 days later.

In situ water temperature at A3 during 2008-2009 ranged from $-1.6^{\circ}$ to $1.9^{\circ} \mathrm{C}$ with a mean temperature of $-1.1^{\circ} \mathrm{C}$ (Fig. 5c).

\section{Discussion}

This is the first study to show year-round production of sound by bearded seals. Throughout this study, bearded seal calls were recorded nearly year-round (i.e., 11-12 months) at all locations in the Beaufort Sea. In a previous study, recordings were made throughout the year in Kongsfjorden, Svalbard, and bearded seal calls were detected only during the breeding season (early April to mid-July). The absence of calls during the fall and winter in that study may have been due to the movement of seals out of the 
fjord and into open water at the end of breeding season (Van Parijs et al. 2001). In the present study, bearded seal vocalizations in the Beaufort Sea were recorded throughout the entire year irrespective of the presence of sea ice or open water.

At all sites, daily call activity was greatest from January to early July with nearly continuous calling (i.e., calls detected in all $24 \mathrm{~h}$ of the day) from mid-March through late June, which coincides with the breeding season for this species (Burns 1970, 1981; Cleator et al. 1989). The fewest hours per day with calls occurred from July to December (minimum in August and November), although at all locations and in both years, there was a slight increase in the number of hours per day with calls in late September or early October.

The overall springtime increase in the number of hours with bearded seal calls at each site is similar to what is known about bearded seals and other pinnipeds. Increased calling during the breeding season and reduced calling outside of these months have been observed in many aquatic-mating pinnipeds (e.g., harbor seals, Phoca vitulina, Van Parijs et al. 1999; Weddell seals, Leptonychotes weddellii, Rouget et al. 2007; Weddell, Ross, Ommatophoca rossii, leopard, Hydrurga leptonyx, and crabeater seals, Lobodon carcinophaga, Van Opzeeland et al. 2010) as well as other species. Not only does vocal activity increase, new call types are also introduced during mating season (e.g., harp seals, Pagophilus groenlandicus, Serrano and Miller 2000). Furthermore, studies have shown correlations between increases in calling behavior and testosterone levels in both terrestrial and aquatic animals (e.g., Bartsh et al. 1992; Marler et al. 2004; Tripovich et al. 2009). Captive male bearded seals did not begin to vocalize until they reached sexual maturity (Davies et al. 2006). These results, in conjunction with studies on other species, support the notion that seasonality in call activity may in part be a reflection of changes in hormone levels.

Another, not mutually exclusive, explanation may account for the seasonal variability of bearded seal call activity. Male bearded seals have been shown to increase their call activity and occupy overlapping territories during breeding season (Van Parijs et al. 2002). In fact, increasing numbers of calls have been associated with an increased number of males rather than an increase in the call rates of individual males (Van Parijs et al. 2001, 2002). It is therefore likely that the increase in the number of hours with calls in this study is indicative of an increase in the number of vocalizing seals within acoustic range of each recorder.

The seasonal peak of call activity in this study was longer than that reported for bearded seals elsewhere (e.g., Van Parijs et al. 2001) although many studies only made recordings from March until June (Cleator et al. 1989; Cleator and Stirling 1990; Risch et al. 2007). Other studies have shown that some aquatic-mating pinnipeds produce calls year-round (Rouget et al. 2007; Van Opzeeland et al. 2010). The year-round occupancy of certain areas may give "territorial" males an advantage over the non-territorial or "roaming" males at the onset of mating season and simultaneous arrival of female seals to the area (Harcourt et al. 2007; Harcourt et al. 2008; Van Opzeeland et al. 2010). The elevated bearded seal call activity in the early winter in the Beaufort Sea suggests that males are engaging in acoustic displays in their breeding territory for a large portion of the year and are, therefore, establishing and defending aquatic territories prior to spring. A similar yearround acoustic presence was observed in Weddell seals (Van Opzeeland et al. 2010).

Wintertime calling of bearded seals was most prevalent at the A1 location, typically intensifying around midDecember and continuing into the spring calling season through mid-late July. Location A1 also had a longer period of increased winter and spring calling behavior (late December through July) in both 2008-2009 and 2009-2010 and almost twice the total number of hours with calls recorded (both years) than either of the other locations. Additionally, the number of hours per day with calls peaked much earlier at A1, beginning January, rather than March. This increased number of hours with calls detected at A1 may be due to its more westerly location in the flaw lead polynya that forms off Barrow (Stirling 1997), making it more accessible to bearded seals earlier in the spring months. The geographic differences in call activity between sites suggest that the area around A1 may be a more important habitat for bearded seals in winter and spring because it may be an area of higher or more enriched benthic productivity, or sea ice conditions at this location may be more suitable for overwintering due to enhanced primary production in the flaw lead polynya or along the sea ice edge (Bluhm and Gradinger 2008). The spatial variation in call activity may also be a result of fine-scale changes in sea ice that are not reflected in the $12.5 \mathrm{~km}$ resolution of our sea ice data. The distribution of vocalizing male bearded seals is dependent on available suitable haul out sites or ice conditions and by female distribution, which is determined by sea ice conditions and ecological requirements (Van Parijs et al. 2001, 2004). Therefore, spatial variation in calling activity of males in the Beaufort Sea may be the result of more females congregating in areas of higher concentrations of prey and thereby influencing the distribution of vocalizing males (Van Parijs et al. 2001; Van Opzeeland et al. 2010).

Although qualitative, the results of this study demonstrate an association between bearded seal call activity and sea ice formation and retreat. The clearest illustration of this is from late June to early July, at all sites and years, where the rapid decrease in number of hours with bearded seal calls responded to the rapid decrease in ice 
concentration. At site A1, there was less than 1 day, in 2009, and less than 1 week, in 2010, between the decrease in sea ice concentration and the decline in bearded seal vocalizations in the summer months. However, at the other two sites, a 2-3 week gap was typically observed between the drop in sea ice concentration and the subsequent decline in call activity.

The relationship between increasing number of hours with calls and increasing ice concentration in the early winter is less obvious, as sea ice concentrations were well above $90 \%$ by the time bearded seals began calling during more than half of the hours available each day $(12 \mathrm{~h} / \mathrm{d})$. However, the interannual differences in the timing of sea ice formation at sites $\mathrm{A} 1$ and $\mathrm{A} 2$ were reflected in changes in the timing of bearded seal call detections. At site A1, sea ice started forming more than 3 weeks later in 2009 than in 2008, and $90 \%$ ice concentration occurred almost 3 weeks later in 2009. The occurrence of bearded seal vocalizations mirrored this interannual difference: $24 \mathrm{~h} / \mathrm{d}$ calling started 1 month later in 2009 than in 2008. A similar pattern was seen at A2. The observed shift in the timing of sea ice formation and call detection between years suggests a change in timing of available sea ice habitat for bearded seals. Extreme variations in available sea ice habitat may have implications for the reproductive success of the bearded seal as well as other ice-obligate species (Moore and Huntington 2008; Kovacs et al. 2011).

This shift in the potential mating or territorial establishment season due to changes in seasonal sea ice formation could affect the mating success of bearded seals by disrupting the timing of key reproductive events. Female bearded seals enter estrous at the end of lactation and mating season typically occurs between March and May (Atkinson 1997). At both $\mathrm{A} 1$ and A2, there were fewer hours per day with bearded seal calls between December and June 2009-2010 than during the same time period in 2008-2009. The reduced call activity may indicate a decline in the number of seals that moved into or established territories in the Beaufort Sea during the spring of 2009-2010, or it might indicate a change in the distribution of bearded seals within the acoustic detection range of the hydrophones. Another possible explanation for the reduced call activity in 2009-2010 may be a result of less suitable habitat in the early winter due to fine-scale changes in local sea ice conditions. Van Parijs et al. (2004) found that between-year fluctuations in local sea ice habitat influenced bearded seal vocal activity by restricting the number of displaying males in the early part of mating season, while less overall ice cover in May resulted in an increase in the number of vocalizing males. Territorial males in Svalbard were present in all sea ice conditions, while roaming males tended to be more restricted by extensive fast ice cover (Van Parijs et al. 2004). Unlike in Svalbard, Van Parijs and
Clark (2006) observed a greater percentage of roaming males than territorial males in the Beaufort Sea. If roaming males are also restricted by fast ice cover in the Beaufort Sea, then fluctuations in ice cover may be of greater importance to a larger percentage of bearded seals in the Beaufort Sea than off Svalbard.

The greatest concentration of bearded seal calls at all locations was recorded during $100 \%$ sea ice cover. These results are somewhat contradictory to those discovered by Simpkins et al. (2003), which showed that bearded seals off of St. Lawrence Island preferred sea ice cover between 70 and $90 \%$ and tended to avoid areas with greater than $90 \%$ cover. However, a more recent study showed that bearded seals seem to be a more "interior" seal species and were typically found on sea ice cover between 25 and $100 \%$ (Ver Hoef et al. 2013). Our results support the more recent findings; however, sea ice concentration in this study is measured at $12.5 \mathrm{~km}$ resolution and averaged over a $20 \mathrm{~km}$ radius. Therefore, the remotely sensed sea ice concentration data may not fully represent the more localized or fine-scale habitat variability, which may be most evident during the freeze-up/retreat seasons, when sea ice conditions are changing rapidly. While the remotely sensed sea ice data may not be on a fine-scale relative to individual bearded seals as it was in prior studies (Van Parijs et al. 2001, 2004; Van Parijs and Clark 2006), it is nevertheless useful in comparing broad-scale relationships. The acoustic data presented here were collected using single hydrophones. This does not allow for localization or abundance assessments, therefore, the exact locations of individual seals relative to the instruments were unknown. All detectable calls were within $20 \mathrm{~km}$ of the recorder, and the sea ice data were averaged over the same distance to account for all vocalizing seals. This comparison may not provide information on bearded seals at the individual level, and the effect of fine-scale sea ice changes, but it does offer a broad-scale view of the influence different sea ice conditions have on the distribution of vocalizing bearded seals in the Beaufort Sea. The association of increased hours/day with calls with increased sea ice concentration supports the idea that bearded seals tend to prefer high concentration sea ice. Furthermore, it demonstrates the exploitation of a stable sea ice platform during mating season.

Water temperature, although related to sea ice, may also be an important factor influencing bearded seal call activity. During the summer months, the ACC carries relatively warm water from the Bering and Chukchi Seas into the Beaufort Sea (Okkonen et al. 2009). Location A1 was positioned along the southern edge of Barrow Canyon and within the prevailing path of the ACC, while sites $\mathrm{A} 2$ and A3 were placed within the downstream extension of the ACC on the upper Beaufort slope. Hydrography data 
collected in the Beaufort Sea from 2005 to 2009 (S. Okkonen pers. comm.) showed a large amount of interannual variability in water temperatures recorded in the ACC. Weak or southerly winds that occur in the Chukchi Sea allow the intrusion of warm Bering/Chukchi waters onto the western Beaufort shelf leading to warmer summer water temperatures recorded in the ACC. Alternatively, summer water temperatures are relatively cool when winds in the Chukchi originate in the north/northeast (Okkonen et al. 2009).

Conductivity, temperature, depth (CTD) data showed that between 2008 and 2010, the warmest recorded water temperatures were found during the summers of 2009 and 2010 (up to $5-6^{\circ} \mathrm{C}$ ) and the coldest were recorded in 2008 (less than $1{ }^{\circ} \mathrm{C}$ ) especially at depths between 70 and $100 \mathrm{~m}$; a range that encompasses the depths at which our recorders (A1 and A2) were moored (S. Okkonen pers. comm). These results support water temperature data recorded on our recorders; warm summer water influxes occurred between 15 August and 15 September in both 2009 and 2010, but did not occur during the same time period in 2008. Water temperature data were not available before 15 August in 2008; therefore it is unknown whether or not the intrusion of warmer water occurred earlier that year. Increased summer water temperatures can delay the formation of sea ice (e.g., fall/winter of 2009) changing the timing of available habitat for bearded seals. The effect on timing of available habitat was reflected in the data presented here when comparing 2008-2009 to 2009-2010; sea ice formed approximately 3 weeks later at sites A1 and A2 in 2009, which resulted in a later detection of increased call activity on the recorders.

Outside of the breeding season, bearded seals were detected as early as late August in all years. There was a consistent presence of bearded seal calls in autumn at all locations from 2008 to 2010 with a slight peak occurring in late September/early October for both years. The autumn presence of bearded seals during the open water period suggests possible year-round residency of a small subpopulation of bearded seals in the Beaufort Sea or the early establishment of aquatic territories by "territorial" males (Van Parijs et al. 2002; Van Opzeeland et al. 2010).

Autumn and winter call activity has a number of possible explanations. Early singing might be related to the development of a vocal repertoire by juvenile or subadult animals or adults may be "warming up" in preparation for breeding season (Davies et al. 2006). Autumn vocalizations were typically lower in frequency and shorter in duration, which may support this latter observation (MacIntyre et al. unpublished data). Alternatively, the different structure of the autumn vocalizations may indicate a functional difference in calls produced by adult males outside of the breeding season (Serrano and Miller 2000). The early season onset might also be due to seasonal changes in testosterone as is well documented for song birds (cf. Smith et al. 1997; Brenowitz 2004) and has been shown for other pinnipeds (captive Australian fur seals, Arctocephalus pusillus, Tripovich et al. 2009; captive walrus, Odobenus rosmarus, Hughes et al. 2011). As noted previously, in many species of pinniped, both land- and aquatic-mating, where males defend a territory or resource attractive to females, males establish these territories well before females give birth and then come into estrous (i.e., Le Boeuf and Peterson 1969; Van Parijs et al. 1999; Kunc and Wolf 2008; Van Opzeeland et al. 2010). The production, duration, and frequency range of trills produced by bearded seals are used by males to advertise quality to other males, and potentially females, as the breeding season progresses (Van Parijs et al. 2001).

Marine mammal distributions in the Arctic are commonly documented using visual surveys (Simpkins et al. 2003; Bengtson et al. 2005). However, such surveys require adequate sighting conditions, including good visibility and low sea state, and are limited by both time of day and surface presence of animals (Mellinger et al. 2007). The relative inaccessibility of the Arctic (poor weather, heavy ice cover and little or no daylight) can make it difficult to assess the abundance, distribution, and behavior of bearded seals. Passive acoustic sampling is robust by comparison, as data can be collected continuously and in all weather conditions (Stirling et al. 1983). During much of the year, this species produces underwater vocalizations, thereby making the utilization of passive acoustics to study them an invaluable tool, particularly in winter months. The biggest drawback of passive acoustic studies of marine mammals is that only animals that vocalize are detectable. Additionally, in the case of bearded seals, only males have been shown to vocalize; therefore, in the current study, only vocalizing males were accounted for (Ray et al. 1969; Davies et al. 2006). However, as this study shows, bearded seals produce sounds all year and the seasonal decrease of sound production occurs in summer when they are more easily studied using traditional visual methods. A combination of these two methods, then, will provide a better understanding of bearded seal occurrence in the Beaufort Sea and elsewhere.

Based on the results of this study, acoustic monitoring can be an effective method to examine the broad spatial and temporal relationship between bearded seal presence and changing sea ice conditions. Differences in sea ice conditions have been shown to influence mating tactics used by males (territorial vs. roaming, Van Parijs et al. 2004) which needs to be taken into account when evaluating the relationship between bearded seals and changing sea ice conditions. With the increased loss of sea ice in the Arctic, there is greater interest in obtaining abundance 
estimations of bearded seals as well as other ice-obligate species. The recent development of methods that utilize passive acoustic detections to provide estimates of density or abundance could be applied to bearded seals (Marques et al. 2012). By combining call rates of these animals (e.g., Van Parijs et al. 2001) with density estimation techniques (Marques et al. 2012), it may be possible to obtain estimates of relative abundance and density of this typically solitary and widespread pan-Arctic species.

Beyond the seasonal and geographic occurrence of the species, acoustic monitoring can provide more information on the acoustic behavior of bearded seals than is presented here. For instance, the methods used in this study to determine bearded seal calling activity do not take into account the number of calls produced by one or multiple seals. The number of hours per day with calls does not reflect the number of calls produced in a given hour; the presence of at least one call per hour was used to document bearded seal presence. A next step is to determine the number of vocal seals (i.e., males) present and determine individual call rates (e.g., Van Parijs et al. 2001; Davies et al. 2006). Future analysis of these data will elucidate whether the increase in the number of hours per day with calls observed in the autumn, winter, and spring months represents an increase in the number of animals present, or an increase in the calling rate of a few individuals, or both. And because it is speculated only male bearded seals produce trills (Ray et al. 1969), any assessment of numbers of animals heard needs to take into account the females that are present, but silent.

Additional investigations into the calling activity of bearded seals will be needed to more accurately assess the relationship between bearded seal seasonal, interannual and geographic calling behavior. Examining call types to compare between seasons might provide insight into the function of autumn and winter bearded seal vocal activity. Expanding the study to the Bering and Chukchi Seas will cover much of the range of Alaskan bearded seals and provide a broader picture of their seasonal occurrence under the different ice conditions they experience over this range. Finally, detailed analysis of call types can be used to determine whether or not geographic variation exists among the three seas as has been shown in other regions and with other species (Van Parijs et al. 1999; Bjørgesæter et al. 2004; Risch et al. 2007; Van Opzeeland et al. 2009). There are potential subpopulations that reside in each region throughout the year that may be determined by comparing call types present throughout the year at each location.

The observed interannual shift in the timing of sea ice formation and retreat between 2008-2009 and 2009-2010 has implications for habitat availability and stability for ice-obligate species if this variability persists (cf. Laidre and Heide-Jørgensen 2005). The results of this study help to explain seasonal vocal activity of bearded seals as well as begin to establish a baseline of bearded seal year-round occurrence in the Beaufort Sea. The institution of such a baseline (although perhaps a decade too late) of bearded seal occurrence in the BCB will permit future detection of changes in bearded seal behavior as sea ice conditions vary with the changing Arctic climate. Additionally, demonstrating the strength of the relationship between bearded seal call activity and sea ice concentration reinforces the claim that extreme variation in their habitat (loss of sea ice) will likely negatively affect bearded seal survival.

Acknowledgments We thank the captain and crew of the USCGC Healy, John Kemp (WHOI), Dave Leech (UAF), and Sharon Nieukirk (OSU) for assistance with deployment and recovery of the moorings. Funding for this project was provided by the National Ocean Partnership Program grants WHOI A100587, and UAF 080047, the Joint Institute for the Study of the Atmosphere and Ocean (JISAO) under NOAA Cooperative Agreement NA10OAR4320148 and the U.S. Department of the Interior, Bureau of Ocean Energy Management (BOEM) Inter-agency Agreement M07RG13317 with the U.S. Department of Commerce, National Oceanic and Atmospheric Administration, National Marine Fisheries Service, as part of the BOEM Alaska Environmental Studies Program. We also thank Steve Okkonen for his assistance with the analysis of our water temperature data and for providing us with data to support our findings. Comments from Dr. Sofie Van Parijs and two anonymous reviewers greatly improved this manuscript. The findings and conclusions in the paper are those of the author(s) and do not necessarily represent the views of the National Marine Fisheries Service, NOAA. Reference to trade names does not imply endorsement by the National Marine Fisheries Service, NOAA. This is JISAO Contribution No. 2095.

Open Access This article is distributed under the terms of the Creative Commons Attribution License which permits any use, distribution, and reproduction in any medium, provided the original author(s) and the source are credited.

\section{References}

Ashjian CJ, Braund SR, Campbell RG, George JC, Kruse J, Maslowski W, Moore SE, Nicolson CR, Okkonen SR, Sherr BF, Sherr EB, Spitz YH (2010) Climate variability, oceanography, bowhead whale distribution, and Iñupiat subsistence whaling near Barrow, Alaska. Arctic 63:179-194

Atkinson S (1997) Reproductive biology of seals. Rev Reprod 2:175-194

Bartsh SS, Johnston SD, Siniff DB (1992) Territorial behavior and breeding frequency of male Weddell seals (Leptonychotes weddelli) in relation to age, size, and concentrations of serum testosterone and cortisol. Can J Zool 70:680-692

Bengtson JL, Hiruki-Raring LM, Simpkins MA, Boveng PL (2005) Ringed and bearded seal densities in the eastern Chukchi Sea, 1999-2000. Polar Biol 28:833-845

Bjørgesæter A, Ungland KI, Bjørge A (2004) Geographic variation and acoustic structure of the underwater vocalization of harbor seal (Phoca vitulina) in Norway, Sweden and Scotland. J Acoust Soc Am 116:2459-2468 
Bluhm BA, Gradinger R (2008) Regional variability in food availability for Arctic marine mammals. Ecol Appl 18:S77-S96

Brenowitz EA (2004) Plasticity of the adult avian song control system. Ann NY Acad Sci 1016:560-585. doi:10.1196/annals.1298.006

Burns JJ (1970) Remarks on the distribution and natural history of pagophilic pinnipeds in the Bering and Chukchi Seas. J Mammal $51: 445-454$

Burns JJ (1981) Bearded seal Erignathus barbatus Erxleben, 1777. In: Ridgway SH, Harrison RJ (eds) Handbook of Marine Mammals, vol 2., SealsAcademic Press, London, pp 145-170

Cavalieri D, Markus T, Comiso J (2004) AMSR-E/Aqua daily L3 $12.5 \mathrm{~km}$ brightness temperature, sea ice concentration, \& snow depth polar grids V002, [18-15-2008-8-15-2010]. Boulder, Colorado USA: National Snow and Ice Data Center. Digital media

Cleator HJ, Stirling I (1990) Winter distribution of bearded seals (Erignathus barbatus) in the Penny Strait area, Northwest Territories, as determined by underwater vocalizations. Can J Fish Aquat Sci 47:1071-1076

Cleator HJ, Stirling I, Smith TG (1989) Underwater vocalizations of the bearded seal (Erignathus barbatus). Can J Zool 67:1900-1910

Davies CE, Kovacs KM, Lydersen C, Van Parijs SM (2006) Development of display behavior in young captive bearded seals. Mar Mamm Sci 22:952-965

Delarue J, Todd SK, Van Parijs SM, Di lorio L (2009) Geographic variation in Northwest Atlantic fin whale (Balenoptera physalus) song: Implications for stock structure assessment. J Acoust Soc Am 125:1774-1782

Frost KJ, Whiting A, Cameron MF, Simpkins MA (2008) Habitat use, seasonal movements and stock structure of bearded seals in Kotzebue Sound, Alaska. Tribal Wildlife Grants Program, Fish and Wildlife Service, Tribal Wildlife Grants Study U-4-IT. Final report from the Native Village of Kotzebue, Kotzebue, AK, for U.S. Fish and Wildlife Service, Anchorage, AK, pp 1-16

Harcourt RG, Kingston JJ, Cameron MF, Waas JR, Hindell MA (2007) Paternity analysis shows experience, not age, enhances mating success in an aquatically mating pinniped the Weddell seal (Leptonychotes weddellii). Behav Ecol Sociobiol 61:643-652

Harcourt RG, Kingston JJ, Waas JR, Hindell MA (2008) Foraging while breeding: alternative mating strategies by male Weddell seals? Aquat Conserv Mar Freshw Ecosyst 17:68-78

Hughes WR, Reichmuth C, Mulsow JL, Larsen ON (2011) Source characteristics of the underwater knocking displays of a male Pacific walrus (Odobenus rosmarus divergens). J Acoust Soc Am 129:2506

Kovacs KM, Lydersen C, Overland JE, Moore SE (2011) Impacts of changing sea ice conditions on Arctic marine mammals. Mar Biodiv 41:181-194

Kunc HP, Wolf JBW (2008) Seasonal changes of vocal rates and their relation to territorial status in male Galapagos sea lions (Zalophus wollebaeki). Ethology 114:381-388

Laidre KL, Heide-Jørgensen MP (2005) Arctic sea ice trends and narwhal vulnerability. Biol Conserv 121:509-517

Le Boeuf BJ, Peterson RS (1969) Social status and mating activity in elephant seals. Science 163:91-93

Marler P, Peters S, Wingfield J (2004) Correlations between song acquisition, song production, and plasma levels of testosterone and estradiol in sparrows. Dev Neurobiol 18:531-548. doi: 10.1002/neu.480180605

Marques TA, Thomas L, Martin SW, Mellinger DK, Ward JA, Moretti DJ, Harris D, Tyack PL (2012) Estimating animal population density using passive acoustics. Biol Rev Camb Philos Soc. doi:10.1111/brv.12001

Maslanik J, Stroeve J, Fowler C, Emery W (2011) Distribution and trends in Arctic sea ice age through spring 2011. Geophys Res Lett. doi:10.1029/2011GL047735
McLaren I (1958) Some aspects of growth and reproduction of the bearded seal, Erignathus-barbatus (Erxleben). J Fish Res Board Can 15:219-227

Mellinger DK (2001) Ishmael 1.0 user's guide. NOAA Tech. Memo. OAR-PMEL-120 (NOAA PMEL, Seattle), pp 1-30

Mellinger DK, Stafford KM, Moore SE, Dziak RP, Matsumoto H (2007) An overview of fixed passive acoustic observation methods for cetaceans. Oceanography 20:36-45

Moore SE, Huntington HP (2008) Arctic marine mammals and climate change impacts and resilience. Ecol Appl 18:S157-S174

Moore SE, Stafford KM, Melling H, Berchok C, Wiig Ø, Kovacs KM, Lydersen C, Richter-Menge J (2012) Comparing marine mammal acoustic habitats in Atlantic and Pacific sectors of the High Arctic: year-long records from Fram Strait and the Chukchi Plateau. Polar Bio 35:475-480

Nelson RR, Burns JJ, Frost KJ (1984) The bearded seal (Erignathus barbatus). In: Burns JJ (ed) Marine mammal species accounts, wildlife technical bulletin no. 7. Alaska Department of Fish and Game, Juneau, AK, pp 1-6

Okkonen SR, Ashjian CJ, Campbell RG, Maslowski W, ClementKinney JL, Potter R (2009) Intrusion of warm Bering/Chukchi waters onto the shelf in the western Beaufort Sea. J Geophys Res. doi: $10.1029 / 2008$ JC004870

Potelov VA (1969) Distribution and migrations of bearded seals in the White, Barents and Kara seas. Third All-Union Conference on Marine Mammals Publishing House "Nauka". (Translated from Russian by Fish Res Board of Can, Transl Ser No. 1510)

Ray C, Watkins WA, Burns JJ (1969) The underwater song of Erignathus (bearded seal). Zoologica 54:79-83

Risch D, Clark CW, Corkeron PJ, Elepfandt A, Kovacs KM, Lydersen C, Stirling I, Van Parijs SM (2007) Vocalizations of male bearded seals, Erignathus barbatus: classification and geographical variation. Anim Behav 73:747-762

Roth EH, Hildebrand JA, Wiggins SM, Ross D (2012) Underwater ambient noise on the Chukchi Sea continental slope from 2006-2009. J Acoust Soc Am 131:104-110

Rouget PA, Terhune JM, Burton HR (2007) Weddell seal underwater calling rates during the winter and spring near Mawson station, Antarctica. Mar Mamm Sci 23:508-523

Serrano A, Miller EH (2000) How vocal are harp seals (Pagophilus groenlandicus)? A captive study of seasonal and diel patterns. Aquat Mamm 26:253-259

Simpkins MA, Hiruki-Raring LM, Sheffield G, Grebmeier JM, Bengston JL (2003) Habitat selection by ice-associated pinnipeds near St. Lawrence Island, Alaska in March 2001. Polar Biol 26:577-586

Smith G, Brenowitz E, Beecher M, Wingfield J (1997) Seasonal changes in testosterone, neural attributes of song control nuclei, and song structure in wild songbirds. J Neurosci 17:6001-6010

Stirling I (1997) The importance of polynyas, ice edges, and leads to marine mammals and birds. J Mar Syst 10:9-21

Stirling I, Calvert W, Cleator H (1983) Underwater vocalizations as a tool for studying the distribution and relative abundance of wintering pinnipeds in the High Arctic. Arctic 36:262-274

Timmermans ML, Proshutinsky A, Krishfield RA Perovich DK, Richter-Menge JA, Stanton TP, Toole JM (2011) Surface freshening in the Arctic Ocean's Eurasian Basin: an apparent consequence of recent change in the wind-driven circulation. J Geophys Res 116, C00D03. doi:10.1029/2011JC006975

Tripovich JS, Rogers TL, Dutton G (2009) Faecal testosterone concentrations and the acoustic behaviour of two captive male Australian fur seals. Aust Mammal 31:117

Van Opzeeland IC, Corkeron PJ, Risch D, Stenson G, Van Parijs SM (2009) Geographic variation in vocalizations of pups and mother-pup behavior of harp seals Pagophilus groenlandicus. Aquat Biol 6:109-120 
Van Opzeeland IC, Van Parijs S, Bornemann H, Frickenhaus S, Kindermann L, Klinck H, Plotz J, Boebel O (2010) Acoustic ecology of Antarctic pinnipeds. Mar Ecol Prog Ser 414:267-291

Van Parijs SM, Clark C (2006) Long-term mating tactics in an aquatic-mating pinniped, the bearded seal, Erignathus barbatus. Anim Behav 72:1269-1277

Van Parijs SM, Hastie GD, Thompson PM (1999) Geographic variation in temporal and spatial vocalization patterns of male harbor seals in the mating season. Anim Behav 58:1231-1239

Van Parijs SM, Kovacs KM, Lydersen C (2001) Spatial and temporal distribution of vocalizing male bearded seals: implications for male mating strategies. Behavior 138:905-922

Van Parijs SM, Lydersen C, Kovacs KM (2002) Vocalizations and movements suggest alternative mating tactics in male bearded seals. Anim Behav 65:273-283
Van Parijs SM, Lydersen C, Kovacs KM (2004) The effects of ice cover on the behaviour of aquatic-mating male bearded seals. Anim Behav 68:89-96

Ver Hoef JM, Cameron MF, Boveng PL, London JM, Moreland EM (2013) A spatial hierarchical model for abundance of three iceassociated seal species in the eastern Bering Sea. Stat Meth. doi: 10.1016/j.stamet.2013.03.001

Walsh JE (2008) Climate of the Arctic marine environment. Ecol Appl 18:S3-S22

Woodgate RA, Weingarter TJ, Lindsay R (2012) Observed increases in oceanic fluxes from the Pacific to the Arctic from 2001 to 2011 and their impacts on the Arctic. Geophys Res Lett. doi: 10.1029/2012GL054092 